Dawid Maria OsińsKi

Uniwersytet Warszawski

\title{
Albumy utraconej rodzinności - \\ o doświadczeniu środkowoeuropejskości \\ w prozie Sándora Máraiego. Kilka przybliżeń
}

\section{W STRONĘ PRYWATNEJ EURopy}

Poddawać namysłowi doświadczenie środkowoeuropejskości w prozie jednego z największych pisarzy węgierskiej i światowej literatury XX wieku - Sándora Máraiego (1900-I989) - to tak, jak pisać o doświadczeniu narodowości, europejskości, nostalgii kulturowej czy historyczno-politycznej w prozie wielkich emigrantów czy wydziedziczonych przez zwroty historii bądź niefortunne zbiegi okoliczności (katalog nazwisk przywołuję tu przy całej świadomości takiej kwalifikacji i różnic): Józefa Ignacego Kraszewskiego (I8I2-1887), Stanisława Brzozowskiego (I878-I9II), Czesława Miłosza (I9II-2004), Milana Kundery (ur. I929). Nazwiska te, poza jednym wyjątkiem (krytyka kultury zmarłego we Florencji w wieku trzydziestu trzech lat), łączy perspektywa wszechstronnej oceny kultury europejskiej i rodzimej, obecna w różnych formach artystycznych - kultury z rysą, raną, traumą (tą przepracowaną i tą nieoswojoną, tą uświadamianą i wynikającą z niewiedzy o własnych fantazmatach narodowych, niedyspozycjach, brakach i niemożliwościach). Perspektywa ta ujawnia również w różnorodnych typach dyskursów, każdorazowo wynikających $\mathrm{z}$ innego kontekstu polityczno-kulturowego, namysł nad zgubnymi skutkami relatywizujących czy wręcz nihilizujących komponentów określających charakter uczestnictwa osobniczego i wspólnotowego w kształtowaniu etycznej odpowiedzialności bycia Europejczykiem.

Łączy je także swoista „długowieczność”, ogarniająca intelektualną refleksją cały wiek europejskich przemian - dziewiętnastowieczność (w przypadku Kraszewskiego) i dwudziestowieczność (jak wynika to z biografii metrykalnej i emocjonalnej pokolenia wieku XX) z jej źródłami w postaci szeroko (i nie tylko umownie) 
pojętej kultury XIX stulecia. Wymienieni tu krytycy dziedzictwa europejskości spinają swoimi biografiami dziedzictwo dwudziestowiecznej Europy z jej przemianami, pęknięciami, możliwościami, z powrotami do różnorodnie pojmowanej europejskiej tożsamości, diagnozą traconych wzorców i zaprzepaszczanych szans oraz koniecznością wykluczenia, z politycznym (wspólnotowym) i biograficznym (indywidualnym) skazaniem na banicję, by móc w pełni oddychać - przy dosłownej nieobecności - autentyczną i poszukiwaną - „lekkością bytu” „rodzinnej Europy”. Ta długowieczność to jednocześnie dar i przekleństwo, które ujawniają, że na konieczność doświadczeń Europy XIX czy XX wieku można być skazanym - metrykalnie i niejako metafizycznie.

Dodatkowo status emigranta i banity wzmacnia tylko proteuszową naturę ,swojego” i „obcego”, dzięki której diagnoza europejskości rysuje w sprzężeniu album utraconej i traconej rodzinności autochtona i wędrowca-tułacza, który swoją odyseję skrupulatnie zapisuje, by - korzystając z okruchów pamięci i podpatrywanych zmian - konfrontować się z dziedzictwem przodków i obecną sytuacją wykluczenia. A tym samym zapisywać i konstruować mapę literackich przygód swojej Europy - mapę indywidualną (poziom „mikro”) i mapę wspólnotową, której kontury są zależne od perspektywy widzenia, a raczej spoglądania. Ta swoiście rozumiana mapa ojczyzny w refleksji węgierskiego pisarza nie wiąże się jedynie z konturem historyczno-politycznym. Niekoniecznie jej wyróżnikami są uwarunkowania przemian społeczno-politycznych, ale „prywatne obowiązki” wobec ojczyzny oraz wpływ peryferyjności i lokalności kultury, w której dojrzewają emocjonalnie pojedyncze jednostki. Kwestia rozumienia przez Máraiego definicji oraz zakresu znaczeniowego ojczyzny i ojczystości jest nieostra, niejednolita, a przez to trudna do jednoznacznego wyjaśnienia. Ojczyznę Sándor Márai definiuje przez perspektywiczne, indywidulane doświadczenia warunkujące istnienie w danym lokalnym/ swoim środowisku, które kształtuje i stabilizuje przez to poczucie identyfikacji. Ale to nie doświadczenie „makro” (historii czy polityki w ogóle) jest tu decydującym wyróżnikiem. Wręcz przeciwnie - każdorazowe, indywidualne spotkania z lokalnymi cechami „małych ojczyzn” określa i kształtuje świadomość przynależności. Tę przynależność wyznacza semantyka spacjalna dobrze znanych („rodzimych”) miejsc - dziecięce miejsca zabaw, szkolne przyjaźnie i namiętności, lektury poznane i zapoznane (odkrywane często po latach na nowo), miejsca młodzieńczych i dorosłych doświadczeń przełomowości poszczególnych biografii - jako prywatne przestrzenie zmiany - będące tym samym metonimiami wielkiej historii - jej przemian, wzlotów, upadków. W Niebie i ziemi stwierdza bowiem pisarz: 
- byliśmy szczęśliwi. Tutaj leży ta równina, ten plac między dwiema bocznymi uliczkami, gdzie toczyliśmy katalaunijską bitwę naszego życia. Tu jest kawiarnia, w której zawarliśmy pokój westfalski. To tutaj, to jest nasz Gauriśankar, szczyt, którego nie potrafiliśmy zdobyć. A to bagno tutaj, to Jezioro Genewskie. Byłaby to precyzyjna mapa, przynajmniej tak prawdziwa jako oro- i hydrograficzna mapa Węgier ${ }^{1}$.

Tekst ten będzie miał charakter kilku przybliżeń, bo - choć nie sposób ogarnąć w sposób całościowy dzieła prozaika węgierskiego, to warto właśnie w taki sposób przyjrzeć się specyfice biograficznej i tekstowej Máraiego uwikłanego w literackim zapisie w swą rodzinną Europę i środkowoeuropejskość jako mapę rodzinności, do której się nieustannie powraca i od której nie można się odwrócić. Przybliżenia, które stosuję wobec spuścizny autora Występu gościnnego w Bolzano (powieści rekonstruującej ucieczkę Casanovy z weneckiego więzienia Piombi), ogniskuję wokół refleksji węgierskiego pisarza na temat rodzinności i europejskości jako wyróżników tożsamościowych definiujących bohaterów i przestrzeń, w której żyją ${ }^{2}$.

Chciałbym pokazać, na czym polega swoista dla tego pisarza (a tym samym doświadczenia Europy Środkowej XX wieku) próba odpowiedzi na pytanie o własną (rodzinną) i europejską tożsamość bohatera tej geopolitycznej mapy. Márai zmaga się $\mathrm{w}$ prozie $\mathrm{i}$ intymistyce $\mathrm{z}$ uwierającą pamięcią o rodzinności, skomplikowanym rozumieniu węgierskości. Proza ta stanowi egzemplum (obok zapisów Miłosza, Brodskiego, Kundery) specyficznego albumu „niemożliwości” i zapisu traumy środkowoeuropejskiego doświadczenia. Skazuje ono na trudne uczestnictwo w rodzimej kulturze. Jej specyfiką obok wielopostaciowości, wielojęzyczności obecnej na terenie kondominium „wpływów” węgierskich, austriackich, niemieckich, czeskich i słowackich, jest mieszanie się paradygmatów lokalnych, zwłaszcza z perspektywy tożsamości językowej, która uwyraźnia niejednoznaczności terytorialne, a sam Márai w tę niejednoznaczność się wpisuje.

1 S. Márai, Mapa, w: idem, Niebo i ziemia, tłum. F. Netz, Warszawa 2011, s. 226. Dalej podaję skrót NiZ i numer strony.

2 Rozumienie rodzinności i europejskości odtwarzam na podstawie spuścizny prozatorskiej Máraiego - powieści: Pierwsza mitość (1928); Wyspa (1934), Wyznania patrycjusza (1934), Dziedzictwo Estery (1939), Występ gościnny w Bolzano (1940), Sindbad wraca do domu (1940), Żar (1940), Pokój na Itace (1952), Ziemia! Ziemia!... (1972); cykl powieściowy: Dzieto Garrenórw (I cz. - Zbuntowani (1930, 1 tom); II cz. - Zazdrośni (1937, 2 tomy); III cz. - Obcy (1931); IV cz. - Znieważeni (1947, 3 tomy: tom I: Gtos (1947); tom II: Znaczek i meldunek (1948); tom III: Sztuka i mitośc (1948; w wersji polskiej tomy Znaczek $i$ meldunek oraz Pogtos. Maruderzy weszły w skałd przetłumaczonej przez Teresę Worowską ostatniej części cyklu, który w tłumaczeniu nosi nazwę Maruderzy); opowiadania (miniatury) z tomu Magia (1941), aforystyczne korpusy poematów prozą: Cztery pory roku (1938), Niebo i ziemia (1942), Księga ziót (1943); reportaże z lat 20. i 30. XX wieku (W podróży) i dziennik $z$ lat 1943-1989. 
Urodził się w I90o roku w Kassie (Koszycach) - jako części monarchii austro-węgierskiej, w której większość ludności stanowili Węgrzy. Koszyce w I9I8 roku (po I wojnie światowej) zostały jednak zajęte przez armię czechosłowacką i włączone do nowopowstałej Czechosłowacji, rok później stały się jednym z ważnych miast Słowackiej Republiki Rad, a w I920 roku przez kilka miesięcy były okupowane przez Węgierską Armię Czerwoną. W okresie międzywojnia odsetek ludności węgierskiej na tym terenie spadł pięciokrotnie. W 1938 roku miasto znowu zaanektowały Węgry, ale w 1945 roku Koszyce zostały zajęte przez Armię Czerwoną i były siedzibą rządu odrodzonej Czechosłowacji ${ }^{3}$. O tym paradoksie politycznego „przeniesienia” (a przez to przeniesienia znaczeń: „swój”/ „obcy”) będzie pisał Márai w cyklu Dzieto Garrenów, w którym podkreśli niejednoznaczność rozstrzygnięcia kwestii przynależnościowej. Kategorie różnicującego powrotu do źródeł, kolekcji „ostatniości” (czyli ostatnich doświadczeń, spotkań, relacji, wydarzeń) oraz melancholii jako tekstowego uobecnienia „braku” języka i poszukiwania przestrzeni, do której można byłoby się odwołać jako do własnej (swoistego „mitu macicznego”) kształtują bowiem refleksję pisarza o traumie „niczego, które boli”.

\section{W STRONĘ MELANCHOLII}

Melancholia Máraiego jest zarówno doświadczeniem egzystencjalnym, jak i pisarskim - narracyjnym i językowym. W jego twórczości przeciw pustce świata, przeciw lękowi przed pustką istnienia powołuje się światy, kataloguje fabularne doświadczenia bohaterów (nader często zderzając je z biografią realizowaną i zapisywaną na kartach dziennika) - jak w Dziele Garrenów, Pokoju na Itace, Wyznaniach patrycjusza, Wyspie, Żarze, nie licząc aforystycznych refleksji i epifanicznych meandrów narracji w Czterech porach roku, Niebie i ziemi czy Księdze ziót. Podobnie w Pierwszej mitości (spisywanym w pierwszej osobie z perspektywy dwudziestu ośmiu lat wspomnieniu - pamiętniku nauczyciela-łacinnika, który decyduje się powrócić do miejsca swej pierwszej placówki (szkoły) i przywołać pierwszą prawdziwą i niemożliwą miłość) czy Dziedzictwie Estery - również pierwszoosobowym wspomnieniu, zapisanym po trzech latach od zaistniałych wydarzeń, jak wyznaje tytułowa bohaterka na początku swej podróży w stronę pamięci. I tak jak w części Dzieła Garrenów - Znieważonych (w przedmowie do powieści bohater wyznaje, że

3 Zob. m.in.: F. Netz, Miasto - mit: Kassa, „Śląsk” 2002, nr 10, s. 29-31; idem, Morfologia wygnania, „Śląsk” 2004, nr 1, s. 36-40; W. Felczak, Historia Wegier, Warszawa 1983; Wegry i dookota Wegier... Narody Europy Środkowej w walce o wolnośc i tożsamośc w XIX i XX wieku. Materiały z konferencji dotyczącej problematyki narodowościowej w Europie Środkowej zorganizowanej z okazji 10. rocznicy śmierci prof. Wacława Felczaka, (Kraków, 12-13 grudnia 2003 r.), pod red. A. Cetnarowicza i S. Pijaja; J. Snopek, Wegry: zarys dziejów i kultury, Warszawa 2002. 
chce „tu zapisać samą prawdę" $)$ - tak w Dziedzictwie Estery kategoria autentyczności i szczerości okazuje się prymarnym doświadczeniem zapisu:

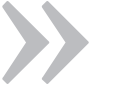

Jeśli mam być szczera - jakiż, $\mathrm{w}$ przeciwnym razie, sens miałoby to pisanie? - muszę wyznać, że w moim życiu i uczynkach nie znajduję śladu owego biblijnego gniewu i pasji, ba, zdecydowania i twardości, jaką częstokroć odznaczały się wypowiadane przeze mnie opinie na temat Lajosa i mojego losu 5 .

Melancholia dostrzegana w narracyjnym zapisie każdej powieści ujawnia zatrzymywanie się fabularnej ciągłości dzięki epifaniom codzienności, kolekcjom utraconych doświadczeń Europejczyka, ojca, pisarza, który wie, że jedynym mechanizmem pomagającym osiągnąć stabilizację, pokorę wobec rzeczywistości, jest pisanie. Słowo, które przechowuje, utrwala, którego nie ma nigdy w nadmiarze, ale też konstrukcje frazy dążące do uchwycenia świata przejrzystego, widzialnego, dotykalnego:

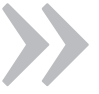

Dzień, w którym Lajos powrócił do nas, przypadł na ostatnią niedzielę września. Był to jeszcze cudownie letni dzień, przezroczysty, jakby ze szkła; babie lato unosiło się pomiędzy drzewami, suche powietrze lśniło i powlekało przedmioty szlachetną emalią, niczym nadzwyczaj rzadkim roztworem, jakby ktoś wszystko, wszelkie zjawiska w zasięgu oka, także niebo, pomalował pędzelkiem zamoczonym w wodnych farbkach ${ }^{6}$.

To doświadczenie środkowoeuropejskiej melancholii, której specyfiką jest próba zatrzymania świata i dziedzictwa historii, ujawnia paradoksy ludzkich relacji, odchodzenia, niemożliwości zrozumienia prawideł rządzących rzeczywistością i nieprzewidywalności reakcji bohaterów oraz masek historii. A środkowoeuropejskość jako kulturową wspólnotę ducha (jakkolwiek zróżnicowaną i niehomogeniczną), nie tylko jako geopolityczny i historyczny konstrukt na mapie, integrowała i wyznaczała osoba cesarza Franciszka Józefa, jak pisze Józef Wittlin w Soli ziemi - wiara w miłościwie panującego Franza Josefa powtarzana litanijnie ,jednoczyła na tych dalekich ziemiach - rzymskich katolików i greckich katolików, Ormian i Żydów - w jeden wspólny i powszechny Kościól”7.

4 S. Márai, Zniezważeni, tłum. T. Worowska, Warszawa 2012, s. 9.

5 Idem, Dziedzictwo Estery, tłum. F. Netz, Warszawa 2008, s. 7.

6 Ibidem, s. 7.

7 J. Wittlin, Sól ziemi, Warszawa 1995, s. 43. 
Przeciw nieumiejętnie odrobionej lekcji dotyczącej przesłanek relatywizmu i nihilizmu, przeciw znikczemnieniu świata, melancholijne „nic, które boli” u Máraiego wyraża zapisywany skrzętnie protest przeciw zacieraniu się, a nawet gubieniu kulturowej specyfiki, by żyć - w języku i dzięki słowu. W pisaniu i w książkach widzi pisarz źródła siły - jak zapisze w dzienniku w 1943 roku $^{8}$, kiedy to w czasie wojny formułuje refleksję objawiającą lęk o to, co stanie się z cywilizacją europejską, „europejską formą życia” (1943; D, 29).

Pisanie jest dla niego jedyną pewnością, daje bowiem gwarancję istnienia i sensu - zapisuje to niejednokrotnie na kartach dziennika prowadzonego od 1943 roku do stycznia I989 roku na kilkadziesiąt dni przed samobójczą śmiercią 2I lutego 1989 roku (w trzy lata po śmierci żony Loli i po starcie przybranego syna Jánosa). Choć skądinąd ma świadomość, że pisarz jest kłamcą, który „Jak każdy inny kłamca, kłamie nawet wtedy, gdy opisuje rzeczywistość przedmiotów. Nie fałszuje faktów - fałszywa jest cała jego istota" (1958; D, 256) ${ }^{9}$.

Melancholia pisarza ma oczywiście też ważne znamię - rozpamiętywania, katalogowania odchodzącej glorii dawnej Monarchii (o której geniuszu nonszalancji wobec „drobnych” $i$ „ważnych” spraw oraz „małym nakładzie inteligencji” pisał Adam Kożuchowski, diagnozując nieuchwytność uroków życia w powieści Roberta Musila Cztowiek bez wtaściwośc $\left.i^{10}\right)$, Węgier wieku XX, których nie może zrozumieć, może je jedynie obrazować w pamięci i języku, by stworzyć alternatywny i jedyny świat, zdolny przechować je w pamięci, która dla autora Magii jest zawsze językowa. Jak podkreśla Wojciech Józef Burszta:

Aby doświadczyć ducha Mitteleuropy, trzeba udać się w wędrów-
kę pamięci, być po trosze archeologiem pamięci, który mozolnie,
warstwa po warstwie, rekonstruuje pokłady kolejnych kultur, jakie
istniały na permanentnie pogranicznym obszarze Innej Europy.
$[\ldots]$ Udać się do zapomnianej części Europy [...] oznacza prze-
kroczyć granicę między orbis interior Zachodu, na którym wszystko
jest poukładane, nudne i przewidywalne, a duch przeszłości żyje

8 S. Márai, Dziennik (fragmenty), tłum., oprac., przypisy i posłowie T. Worowskiej, Warszawa 2009, s. 29. Dalej w tekście stosuję skrót: rok zapisu; D i numer strony.

9 L.F. Földényi zwraca uwagę na dwie główne przyczyny, które skłoniły pisarza do prowadzenia dziennika: „Pierwsza miała związek z pospolitowaniem polityki: ze stopniowym dryfowaniem ku postawom prawicowym, z następującymi po sobie „ustawami żydowskimi”, z coraz większymi ustępstwami na rzecz hitlerowskich Niemiec - wszystko to wystarczyło, by Márai wybrał emigrację wewnętrzną. [...] Drugi powód to narastające niezadowolenie z dotychczasowych osiągnięć pisarskich". L.F. Földényi, Ostatni z ostatnich patrycjuszy. O dziennikach Sándora Máraiego z lat 1943-45, tlum. K. Piotrowiak-Junkiert, „Tekstualia” 2013, nr 3(34), s. 172.

10 A. Kożuchowski, Pośmiertne dzieje Austro-Wegier. Obraz monarchii habsburskiej w piśmiennictwie międzywojennym, Warszawa 2009, s. 147-148. 
tylko w muzealnych salach, i wkroczyć w orbis exterior, w ramach którego wszystko się jeszcze może zdarzyć, jako że historia nie została tam zamrożona ${ }^{11}$.

Świadomość zniewolenia i poczucia koniecznej banicji czy separacji z Węgrami i w ogóle z Europą Środkową, kiedy Máraiowie popłyną za ocean do Ameryki, stają się namacalnym gestem symbolicznego zerwania. Zerwanie to nigdy jednak nie nastąpi w języku, bo w przeciwieństwie do niektórych pisarzy emigrantów - czeskich, polskich czy rosyjskich - Márai (choć zna świetnie co najmniej kilka języków) pisze do końca w języku węgierskim. Idea wolności w doświadczeniu i zapisie traumy środkowoeuropejskości u Máraiego ma znamiona melancholijnego i wyobrażonego (a przez to utopijnego) gestu powrotu. Jak dowodzi Lászlo F. Földényi w swej monumentalnej monografii dotyczącej specyfiki rozumienia kulturowych i psychologicznych źródeł melancholii na przestrzeni dziejów:

Europejczyk nie zajmowałby się tak wytrwale ideq wolności, gdyby co i rusz nie zmuszało go do tego doświadczenie braku wolności. [...] Wieczne czekanie to stan nieznośny. Podkopuje zdrowie, podstępnie niszczy gospodarkę psychiczną. A jednak Europejczyk czeka bezustannie: na spełnienie, na zbawienie, na łaskę, szczęście, rozgrzeszenie. Jednym słowem: czeka na wolność. Jego tęsknota jest tak silna, że nawet w śmierci chciałby dostrzegać maskę wolności. Jego fantazja stale jest trzymana w szachu przez Innego, a dokładniej: przez to, co on sam uważa za inne, co zatem nie jest tożsame z jego ,ja”. W nim rozpoznaje, jak mniema, to wszystko, czego brakuje mu we własnym życiu. [...] Poszukuje zatem pociechy we wspomnieniach. [...] Ufa nieznanej przeszłości i nieprzewidywalnej przyszłości. Ale to wszystko czyni w teraźniejszości - w owej teraźniejszości, z której pragnie się wyrwać, a w której właśnie odczuwa brak tego, z czego żyją jego przeszłość i przyszłość: wolności ${ }^{12}$.

W kontekście biografii i strategii pisarskich Máraiego (poza specyficznym dla niego doświadczeniem teraźniejszości, które „zakotwicza” płynną rzeczywistość, czyniąc ją bardziej statyczną) można to uznać za niezwykle trafną diagnozę.

11 W.J. Burszta, Duch Mitteleuropy dzisiaj, w: Procesy autoidentyfkacji na obszarze kultur środkowoeuropejskich po roku 1918, red. J. Goszczyńska, Warszawa 2008, s. 77.

12 L.F. Földényi, Pustka stworzenia, w: idem, Melancholia, tłum. R. Reszke, Warszawa 2011, s. 255-256. 


\section{W STRONę Europy ŚrodKoWEJ JAKo DOJRZEWAJĄCEJ EMIGRACJI}

Urszula Górska, definiując różnorodne koncepcje Mitteleuropy, poszukuje określeń i wyróżników bohatera prozy środkowoeuropejskiej i diagnozuje zasadność utrwalanych i kontestowanych operacyjnych definicji środkowoeuropejskości. Bazuje na rozpoznaniach geopoetyki ze szkoły Kennetha White'a czy socjologów i kulturoznawców (Lasmane, Schultz) oraz wskazuje na - ważne w kontekście próby zrozumienia przeze mnie pojęcia środkowoeuropejskości u Máraiego - ruchome sensy znaczeń naddanych tej przestrzeni: „Środkowoeuropejska kraina poddana została grze wielorakich struktur kulturotwórczych rozbijających stary szablon egzystencji, deformujących bądź scalających go powtórnie, przekształcając go w nowy typ istnienia zakładającego pluralizm tożsamości kreowanej nieustannie dzięki koegzystencji różnic" ${ }^{13}$.

Z taką świadomością podchodzę do zapisów i diagnoz Máraiego, który pokazuje Europę Środkową jako swoisty „produkt” wymiany polityczno-gospodarczo-kulturowej. Na kartach dziennika, ale i powieści pisanych od lat 3o. XX wieku, widać, że pisarz ma świadomość przejściowości tej przestrzeni i znaczenia środkowoeuropejskości jako konstruktu w myśleniu i propozycjach niemieckich, austriackich czy węgierskich historiografów i ich projektów politycznych drugiej połowy XIX i pierwszej połowy XX wieku. Europa Środkowa Máraiego to obraz nie tyle rodzinnego albumu z „płaskostopiem” (termin Aleksandra Kaczorowskiego ${ }^{14}$ ), ile pękniętej i pozostawionej działaniu obcych wpływów „Róży Wiatrów” (propozycja Andrzeja Tyszki ${ }^{15}$ ), której środkiem jest dowolne miejsce pod warunkiem, że pierwotnie doświadczone przez samego pisarza jako miejsce własne. Przywołany tu Aleksander Kaczorowski podejrzliwie patrzy jednak na samą istotę i ideę myślenia o Europie Środkowej. Przyczyną takiego stanu rzeczy jest nieadekwatność zastosowania operacyjnej kategorii Europy Środkowej - wspólnoty historyczno-kulturowej niezgodnej z prawdą w związku z silnymi w tym rejonie antagonizmami i różnicami emocjonalnymi, mentalnościowymi. Kaczorowski podaje tu przykład wzajemnych niechęci „zniemczonych” Czechów, „słowiańsko nastawionych”, a ponadto uciśnionych

13 U. Górska, W poszukiwaniu tożsamości Europy Środkowej. Przypadek bohatera galicyjskiego, Warszawa 2012, s. 26.

14 A. Kaczorowski, T. Maćkowiak (współpraca), Europa z płaskostopiem: rozmowy, Wołowiec 2006.

15 A. Tyszka, Stowo wstępne. Od rodzimości do uniwersalizmu i vice versa, w: Róża Wiatrów Europy. O środkowoeuropejskiej tożsamości kulturowej, red. A. Tyszka, Warszawa 1999, s. 10-12. Tyszka pisze: „Środkiem Róży Wiatrów może być dowolne miejsce. Jeśli wykreślimy ją z wybranych punktów danego obszaru, rysunki promieni przetną się pod różnymi kątami jak na starodawnej mapie. Otrzymamy metaforę radiacji i krzyżowania się kultur, wpływów kulturowych. Zawiera system wektorów skierowanych na zewnątrz, obrazujących opcje i transcendujące dążenia. Róża Wiatrów rozpościera się na wszystkie strony świata. [...] Każdy promień naszej Róży Wiatrów jest interesujący kulturowo, kryje zarówno korzyści, jak i niebezpieczeństwa" (ibidem, s. 12). 
Słowaków i dominujących Węgrów, pragmatycznych Czechów i romantycznych Polaków. Identyfikacja Europy Środkowej z Zachodem wyklucza Rosję ze wspólnoty i idea ta okazuje się sama narzędziem wykluczenia:

Wiedzą coś o tym Słowacy, Słoweńcy, Litwini, Białorusini, Rumuni
czy Chorwaci, a nade wszystko Ukraińcy, którzy z uzasadnionych po-
wodów historycznych, kulturowych i politycznych czyją się nie gorszy-
mi obywatelami Europy Środkowowschodniej i Europejczykami niż
Polacy, Czesi i Węgrzy, lecz nader często nie byli - i często wciąż nie
są - za takich uznawani. Czas więc pogrzebać tę nieszczęsną Europę
Środkową. Odegrała swoją rolę, lecz dziś nie przynosi już pożytku ${ }^{16}$.

Europa Środkowa dla Máraiego to wielokulturowy projekt rozbitej tożsamości, zapisany projekt politycznej przestrzeni, której daleko do statusu federacji państw. Gdyby użyć kategorii geopoetyki, wypadałoby uznać, że w całym pisarstwie Máraiego Europa okazuje się bardziej zapisywanym projektem kulturowym, do którego nie można dotrzeć i który konstruuje się jako idealny wzorzec, zastępnik czegoś, co się straciło. Tym bardziej istotny to rys refleksji w myśleniu samego Máraiego i bohaterów jego powieści, jeśli uwzględni się status pisarza jako emigranta. To kolejne newralgiczne i trudne do zdefiniowania określenie przynależności. Trudność ta wynika bowiem z niestandardowych i niepolitycznych w zasadzie pobudek wyjazdu. Choć określeniem emigranta i pojęciem emigracji posługuje się w swych rozpoznaniach badaczka, znawczyni i tłumaczka spuścizny pisarza, Teresa Worowska, to warto dodać, że emigracja Máraiego, prócz uniknięcia represji z powodu druku artykułów w gazecie, która stała się ,nieprawomyślna”, wynikała także ze specyficznej sytuacji - decyzji domowej, namów ojca, a wreszcie z pasji poznawczej $^{17}$. Ta poznawcza emigracja na kilka lat, choć zakończona decyzją powrotu do kraju i osiedlenia się w Budapeszcie w I928 roku - podobnie jak drugi wyjazd - tym razem bezpowrotny (wynikający w dużej mierze z konsekwencji krytyki marksistowskiego teoretyka literatury Györgya Lukácsa i pozbawienia możliwości publikowania) - dopiero w trakcie jej trwania została uznana za polityczną. Choć warto uzmysłowić sobie to, że młody pisarz, podobnie jak później czterdziestoośmiolatek - wyjeżdża z potrzeby poznawania Europy i europejskości, a potem

16 A. Kaczorowski, T. Maćkowiak, op. cit., s. 223.

17 Sándor Márai był emigrantem dwa razy. Pierwszy raz opuścił ukochane Węgry z własnej inicjatywy w październiku 1919 roku i udał się do Niemiec, następnie do Francji, skąd powrócił w 1928 roku. Emigracja spowodowana była uniknięciem represji z powodu druku artykułów w „Czerwonym Sztandarze” po upadku Węgierskiej Republiki Rad. Zob. T. Worowska, Świadek entropii [posłowie], w: S. Márai, Dziennik (fragmenty), op. cit., s. 615. 
Ameryki - poznawania naskórkowo, namacalnie, by podróżować ${ }^{18}$ wedle własnych zasad, oglądać i zwiedzać we własnym tempie, nieustannie korygować siebie wedle własnych potrzeb, pracować we własnym trybie, $\mathrm{z}$ wolnym niebem nad głową i wolnym wyborem patrzenia $z$ dystansu na środkowoeuropejskość i rodzinność, do której nie chce się wrócić. Nazwanie Máraiego emigrantem, a jego doświadczenia emigracją - to określenie pewnego typu dyspozycji kulturowych i sposobu przeżywania rodzinności, a także wyniku decyzji pisarza, by nie wracać na Węgry nawet wtedy, kiedy polityczna „zmiana warty” umożliwia to już dojrzałemu twórcy.

Rezultatem doświadczenia wyjazdu w I9I9 roku były drukowane jeszcze na emigracji i pisane później kartki wspomnień, odpryski doświadczeń europejskich, które złożyły się na tom $W$ podróży. Migawki dotyczące kuchni francuskiej, statusu korespondenta francuskiego, pasaży paryskich, obrazów (a raczej powidoków) Lido, Nicei, Bretanii, podróży statkiem po Morzu Śródziemnym, panoram Wenecji i Florencji, Rzymu, Tyrolu, Trypolisu, Morza Martwego, Kairu w noc Bajramu, aury Jeziora Bodeńskiego, Wiednia - są swoistymi „widokówkami” dziewiętnastowiecznych z ducha doświadczeń miejskości w Europie Zachodniej i Południowej. Ale to również tutaj zapisuje Márai w szkicu Mesjasz w Patacu Sportu (29 I I933), jak wygląda Berlin czterdziestosześcioletniego Hitlera (wegetarianina i abstynenta, specyficznego ascety-wodza) oraz Goebbelsa.

Młody pisarz wyznaje w szkicach $W$ podróży, że Wiedeń to jedyne miasto, w którym mógłby żyć ${ }^{19}$, miasto ponurych kamienic, kuchennych zapachów, sympatycznych dziewcząt, żółtych pałaców, emerytowanych pisarzy i artystów. Z kolei doświadczenie uczestnictwa w miejskim ruchu Saint-Malo, Chartres czy Bergen powoduje, że wspomnienia przenoszone na papier nie potrafią tych miejsc rozdzielić i opisać selektywnie, pojedynczo, jednocześnie hierarchizując je i wartościując. Powroty pamięci dokonują się tu jednocześnie całościowo i wybiórczo, miasta te przypominają bowiem Máraiemu utraconą młodość. Architektura miast francuskich i doświadczenie flâneura wśród pasaży i widoków miejskości okazuje się metonimią młodości, a wspomnienie ma siłę zamiany nieporównywalnych ze sobą doświadczeń, emocji i zjawisk.

Drugi wyjazd emigracyjny dojrzałego już pisarza miał miejsce we wrześniu 1948 roku w związku z przybraniem na sile kursu lewicowego na Węgrzech ${ }^{20}$. Ale ciekawym jest to, że nieufność wobec ziemi rodzinnej ujawnia „nieostrośč doświadczania

18 Na doświadczenie podróży jako wyznacznika jakości egzystencji w biografii Máraiego zwraca uwagę Irena Makarewicz. Zob. I. Makarewicz, Paryż-Koszyce-Nowy Jork-Budapeszt-Salerno: śladami Sándora Máraiego, „Topos” 2009, R. 16, nr 4, s. 29-35.

19 S. Márai, $W$ podróży, wybór, tłum. i posłowie T. Worowska, „Zeszyty Literackie”, Warszawa 2011, s. 191. Dalej stosuję skrót Wp i numer strony. 
owego „kursu” politycznego, skoro młody Márai w młodości zamieszany w epizod socjalistyczny, po II wojnie wyjeżdża z powodu socjalistów. Po latach w I965 roku w dzienniku napisze:

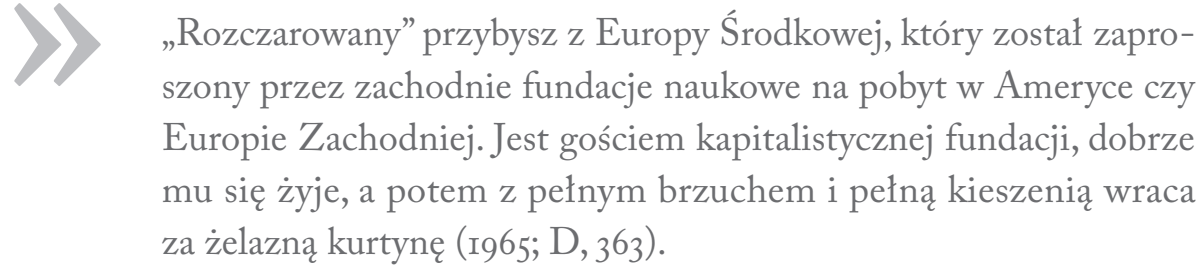

\section{W STRONĘ MIASTA}

Zapis diarystyczny dokonywany jest od początku z perspektywy obecności najważniejszych komponentów stoicyzmu jako terapii na oddalenie, poddawany refleksji swedenborgiańsko-kierkegaardowskiej dotyczącej zarówno egzystencjalnego strachu, jak i istoty chrześcijaństwa czy wiary, a raczej wątpienia w nią. Powroty i poszukiwania definicji europejskości i rodzinności to dla pisarza jedno z najważniejszych i koniecznych do odnalezienia siebie - doświadczeń, dokonujących się przez poszukiwanie języka i modlitwy (1957; D, 247), by odnaleźć utraconą część identyfikacji. Stoicyzm starożytnych - mistrzów przetrwania (a przywołuje się Lukrecjusza [1947; D, I23] czy Marka Aureliusza) okazuje się pomocną lekturą - księgą doświadczania pokory oraz dystansu wobec świata i złudzeń. Pomaga zrozumieć pęknięcia rodzinności, prywatności, starości, a także swoistej niesubordynacji kultury europejskiej - zwłaszcza dziedzictwa zachodniego, łacińskiej Europy, która nie umie wykorzystać lekcji historii. Zapewne mając na względzie te komponenty myślenia węgierskiego epika, Marta Wyka, diagnozując narrację diarystyczną wielkich dwudziestowiecznych pisarzy - Manna, Márqueza i Máraiego, nazywa autora Księgi ziót-śmiertelnym ${ }^{21}$. Marek Szladowski, powołując się na rozpoznania Georga Christopha Lichtenberga (z Pochwaty watpienia) i Ryszarda Przybylskiego z esejów o starości (Baśni zimowej), dokonuje z kolei oceny przygody życia, starzenia się i umierania w diarystyce Máraiego, określając tym samym obecną w nich świadomość cielesności starca:

\section{Uwikłanie w przygodę starości staje się dla Máraiego równocze- śnie poznawczym, egzystencjalnym i estetycznym doświadczeniem. Epistemologia własnej twarzy prowadzi do zachwiania procesu au- toidentyfikacji. Swoiste starcze piętno Narcyza powoduje, iż status}

21 M. Wyka, Czytanie dziennikórw, pisanie dziennikóww, „Tygodnik Powszechny” 2005, nr 8. 
„ja” zostaje zachwiany i podważony. Bycie sobą staje się byciem kimś innym, obcym, nierozpoznawalnym. W ten proces przemiany wyraźnie wpisuje się też fizyczna metamorfoza, połączona z estetycznym upadkiem $^{22}$.

Europa Środkowa, a w szczególności Węgry, nigdy nie okazały się w prozie Máraiego miejscem czy przestrzenią nudy, której doświadczenie można by w pewnym sensie łączyć z doświadczeniem melancholijnego „zamrażania” doświadczenia. Tym bardziej - jako rewers Europy Środkowej - pisarz ujawnia powolność i rozleniwienie Londynu w Wyznaniach patrycjusza. Tu w całej Anglii panuje nuda metodyczna, w stolicy Wielkiej Brytanii natomiast „podniecająca i sekretna nuda”23. Atmosfera Londynu przesycona jest erotyką, to miasto dla samotnych (WP, 449):

Londyn był jak sanatorium, do którego co jakiś czas wyjeżdżałem, jak ktoś, kto stosuje dietę i kurację, brałem zimny prysznic w rozciągającym się nad wyspą sanatoryjnym spokoju. Lubiłem przyjeżdżać do Londynu i lubiłem wyjeżdżać z Londynu (WP, 445-446).

Londyn jest prawdziwą kliniką dla tych, którzy noszą w sobie środkowoeuropejski Minderwertigkeitskomplex. Mężczyzna z kontynentu czuje się w Londynie jak wygnaniec i trędowaty, a jednocześnie jak wytworny cudzoziemiec, chroniony respektowanymi prawami eksterytorialności (WP, 449).

Już w Paryskich niedzielach ( $W$ podróży) dojrzewający w warsztacie Márai porówna Londyn z Paryżem. Stolica Wielkiej Brytanii wyda mu się w niedzielę pusta, ale cieplejsza i bardziej ludzka (Wp, 44), niedzielny Paryż zaś „okrutny i przerażający. To miasto, gdzie można tylko pracować i używać” (Wp, 44). Ów kompleks niższości niejako z natury w przestrzeni obcej i cudzej, anonimowej, umożliwiającej samotność, dla przybysza okazuje się właściwym rewersem rozpoznania tożsamości - indywidualnej, ale przede wszystkim wspólnotowej. Choć wspólnota środkowoeuropejskości to wspólnota „kulawa”, przetrącona, bolesna i trudna do określenia. W Niebie i ziemi zadeklaruje wyraziście:

22 M. Szladowski, „Starzenie obserwuje w sobie, na sobie tak, jak coś w rodzaju przygody”. Starość Sándora Máraiego, w: Egzystencjalne doświadczenie starości w literaturze, pod red. A. Glenia, I. Jokiel, M. Szladowskiego, Opole 2008, s. 56.

23 S. Márai, Wyznania patrycjusza, tłum. i posłowiem opatrzyła T. Worowska, Warszawa 2005, s. 445. Dalej w tekście stosuję skrót WP i podaję numer strony. 
W oficjalnej ojczyźnie, w ojczyźnie historycznej, ojczyźnie od godła i sztandaru, policyjnej i wojskowej, kodeksowej i hasłowej, zawsze na nowo, z narastającą, coraz boleśniejszą uwagą, z wytrwałością, czułością i wyrozumiałością trzeba szukać prawdziwej ojczyzny, która może jest językiem, może dzieciństwem, może pewną ulicą z dwoma rzędami platanów, może bramą, w której kiedyś stałem, słuchając pewnej melodii, jaka przez okno mieszkania na pięterku wyfrunęła na świat, a może słowami: „zorza wieczorna”... Zawsze szukałem tej ojczyzny z narastającą miłością i uwagą, jako że przesłania mi ją ta druga, oficjalna i historyczna, ta od godła i sztandaru (NiZ, 30).

Ważną przestrzenią identyfikacji w Wyznaniach patrycjusza jest imponująca i monumentalna w swym wyglądzie biblioteczka matki, stojąca w palarni w trzydrzwiowej oszklonej szafie $z$ licznymi lekturami niemieckich pisarzy i poetów - Schillera, Goethego, Freytaga, Herzoga, Stratza, Omptedy, Klopstocka, ale także z książkami: Karin Michaelis, Gyuli Wernera, Kálmána Mikszátha. To one kształtują samoświadomość, są znakiem umożliwiającym rozpoznanie narodowości, lekcją narodowego języka, a zarazem języków europejskiego doświadczania tożsamości. Dlatego też Wyznania patrycjusza są dialogiem z Buddenbrookami, powieścią, która ukazała się w milionie egzemplarzy (WP, 366$)$ i wychowała nowe Niemcy (inne niż Niemcy Goethego), przyczyniając się do zmiany mieszczańskiej kultury. Przyczyniła się również stworzenia opisu ikon mieszczańskiego kodu porozumienia i systemu wartości świata, który w powieści cały utkany jest z kolekcji doświadczeń, zjawisk, rzeczy. Ponadto pisarz oddaje tutaj niewątpliwie autobiograficzny rys domowej atmosfery inteligenckiego mieszczańskiego domu rodzinnego.

\section{W STRONĘ ODYSEI PAMIĘCI}

Węgry, dawną świetność Monarchii i tożsamość środkowoeuropejską Márai niesie niejako nie tylko w pamięci, lecz także i przede wszystkim konstruuje ją w języku powieściowych światów, których fabularność tworzy niekończącą się opowieść, choć posiada niejednolitą strukturę opartą na migotliwości doświadczeń, epifanii zjawisk i zdarzeń, fragmentarycznego doświadczania siebie i rzeczywistości przez bohaterów tej prozy. Te właśnie wzory opowiadalności kształtują się w jego pisarstwie różnorodnie - to kolekcje światów utraconych, aforystyczne katalogi zjawisk, próba punktowego obrazowania rzeczywistości, którą się traci, ale z którą ma się metafizyczny (bo faktycznie niemożliwy do ujęcia i opowiedzenia) kontakt. Należy zatem zapisać najwięcej, przywołać do istnienia, stworzyć na nowo krajobraz, z którego zostało się wydziedziczonym. Życie w podróży niejako z konieczności 
i wyboru to trudny los emigranta, wiecznego Odyseusza, jak Márai sam siebie nazywa. Dlatego też zaproponuje alternatywną, uwspółcześnioną wersję Odysei w trzech pieśniach (Pokój na Itace) z idyllicznym finałem losów Penelopy, Telemacha i Telegonosa. Tu Ulisses będzie wędrował dalej. Sam fakt dyskusji z eposem i próba ujęcia retrospektywnej oraz retardacyjnej funkcji przełomowości i dziejowości w ruchu przemian kulturowo-świadomościowych to kolejny gest Máraiego, zmierzający do tego, by uchwycić niepochwytne, by zdążyć zapisać „ostatniość”, która odchodzi, a zmieniając bieg losów Ulissesa - przywrócić dzięki mitotwórczej aktywności i przewrotnemu, choć potrzebnemu ludziom dialogowi, wiecznotrwałą postać i nośność mitu jako znaku odniesienia i pewnika (lub wyróżnika) każdej tradycji, którą utrwala pieśń, oralność, zapisanie w pamięci dzięki kolejnym wariantom opowieści, zniekształcając czasami jej tkankę fabularną, ale powodując dzięki temu, że zarówno logos, jak i bios mitycznej opowieści żyje i trwa kilka tysięcy lat.

Podobnie jak gest zdystansowanego aforysty w miniaturach o meandrycznym charakterze i wielkiej potencji kodowania sensów (swoistych poematach prozą, diagnozujących paradoksy, rozbijających pewniki i wyobrażenia o świecie, doświadczeniach i ludziach) - w cyklu zapisów Niebo i ziemia (1947), definiując rozbieżność mechanizmów zegarów życia i zegarów historii, niewybijających poważnie południa i północy, Márai zapisze:

Od roku I867 do I9ı2 ludzie mieli takie uczucie, jakby stale był kwadrans na trzecią lub wpół do dziewiątej. Potem wskazówka zaczęła cwałować i raptem wszystkie zegary pokazywały północ. Natomiast teraz żyjemy tak, jakby ktoś gdzieś ze stoperem w ręce odliczał upływ sekund (NiZ, I4).

Środkowoeuropejskość, zdaniem twórcy, to nie tyle los Jezusa czy Fausta - ile los Odyseusza (zapis w dzienniku w I949 roku $^{24}$ ). Transformacja mitu śródziemnomorskiego jest tu celowym przesunięciem znaku i desygnatu. Służy jako określenie czegoś nieswojego, traconego, melancholijnego pragnienia. Márai jest Odyseuszem i Sindbadem nie tylko wtedy, gdy śni swój „mit maciczny” i podróżuje po mapie Europy w powieściach i dzienniku, lecz także dosłownie, kiedy komponuje wzorzec biografii Guyli Krúdy'ego w swej powieści Sindbad wraca do domu. Pisarz to wieczny żeglarz, który powinien zawsze słuchać swojej ojczyzny, skoro zapisze on w Księdze ziót:

24 Cytuję za posłowiem Teresy Worowskiej: Niepokojąca wieloznacznośc, w: S. Márai, W podróży, op. cit., s. 198. 


\section{Słuchaj tylko swojej ojczyzny.}

Zawsze, wszystko oddaj ojczyźnie. Świat bez twojej ojczyzny nie ma dla ciebie żadnej wartości. Nie oczekuj od niej dobra, i nie lamentuj, gdy cię skrzywdzą w imieniu ojczyzny. To nieistotne. W ogóle, niczego nie oczekuj od ojczyzny ${ }^{25}$.

To pragnienie żeglugi i wędrówki generuje sensy twórcze, prowokuje do pisania, do stwarzania światów zaklętych w słowie, by umożliwić im fikcjonalne istnienie, a przez to przywołać je w pamięci. Żeby konstruować niemożliwe, powołać do istnienia utopijne wyobrażenie świata, który jest konstruktem, ale dzięki któremu przekracza się niemożliwe.

\section{W STRONĘ NIEMOŻLIWEgo}

Márai to pisarz z ducha dziewiętnastowieczny, mag słowa, opowiadacz, podobny do Manna, Jamesa, Singera, Prusa, nawet Orzeszkowej. Jest świadomy tego balastu dziewiętnastowieczności i przełomowości swojej biografii, naznaczonej niejako znakiem czasu minionych doświadczeń. W 1943 roku w zapisie dziennikowym stwierdzi: „Urodziłem się na przełomie epok, trzeba to znieść z pokorą” (1943; D, 30).

Zbiera i zapisuje myśli, które ujęte są w dukcie fabularnym powieści, a w dzienniku tworzą sekwencje różnorodnych zapisów (jak w Piesku przydrożnym Miłosza) i służą zapisywaniu traconej Europy, krytyce wydziedziczenia, znieprawienia kultury i cywilizacji europejskiej, są wieczną dyskusją z dziedzictwem. Choć warto też dodać, że druga emigracja ${ }^{26}$ przyczynia się do takich zapisów w dzienniku, w których widać niechęć powrotu do rodzinnej Kassy okupowanej przez komunistów, uzasadniając ponadto niezezwolenie na przedruki powieści w kraju, który plami się krwią.

Proza Máraiego to album traconych wzorów, z którymi czasami na siłę próbuje pisarz dialogować, by nawiązać $\mathrm{z}$ nimi kontakt, utrwalić je w świadomości i powołać do istnienia nowe sensy. Dziennik, utkany z gloss i zapisków, jako album-kolekcja myśli uzbieranych i zapisanych pozwala spotkać obok siebie różnorodne obrazy: bombardowania Sofii czy Budapesztu z czasów II wojny, upalnych dni w okupowanych Węgrzech, zajęcia Węgier przez Niemcy, uczestnictwa w „podziemnym” życiu węgierskiej wspólnoty, impresje na temat istoty przeżywania żydowskości przez Simone Weil (kwestii ważnej w kontekście religijności żony pisarza - Loli),

25 S. Márai, O ojczyźnie, w: idem, Ksiegga ziót, tłum. F. Netz, Warszawa 2011, s. 150.

26 Należy podkreślić, że emigrantem - w kontekście diarystycznego zapisu Máraiego i jego technik pisarskich - nazywa go Konrad Ludwicki. Zob. idem, Sándor Márai - antropolog, emigrant, humanista (rozważania o istocie pisarstwa Maraiego na przyktadzie „Dziennika”), „Studia i Materiały Polonistyczne" 2009, T. 9, s. 83-92. 
charakter dziedzictwa Goethego, wędrówek z przybranym synem po Metropolitan Museum, widoku chińskiej pralni na rogu ulicy. Obok znajdują się impresje lekturowe z W poszukiwaniu straconego czasu Prousta, Anny Kareniny Tołstoja, wierszy angielskich, fragmentów wspomnień Tadeusza Borowskiego w czasopiśmie amerykańskim, które to wspomnienia rozrachunkowe o nieprzemijającej wartości nazywa diarysta bardziej plastycznymi od realistycznych szczegółów Archipelagu Gułag Sołżenicyna, a zapis ten przywołuje powracający koszmar wojny. Mnogość diarystycznych tematów, wątków, notatek na temat zmieniającej się rzeczywistości pozwala zapisywać również to, w jaki sposób można radzić sobie z trudnym doświadczeniem upiornej pamięci, w której nie pozwalają zapomnieć o minionym chaotyczne sny i przywidzenia. Dlatego też tak ważne w jego spotkaniu z przeszłością jako rodzinną rysą i europejskością są dygresje literackie na temat koegzystencji światów Trevor-Ropera, znajdowania sensu w egzystencjalizmie spod znaku Ortegi, miniatury poetyckie ujmujące doświadczenie malarskie Vermeera, który „zawsze malował «to samo»: zjawisko mieszczaństwa w renesansowym mieście” (1958; D, 259), zapisane sposoby i „charakter” odchodzenia ludzi, zjawisk, rzeczy. Obok tych zapisów pojawiają się próby szukania diagnozy coraz większego umasowienia kultury, niszowości kultury wysokiej, stąd refleksje na temat transmitowanej piątej symfonii Beethovena pod dyrekcją Karajana (I977; D, 489), pisane słowem pocztówki o charakterze ekfraz codzienności miejskiej z włoskich miast czy refleksje na temat neapolskiego muzeum antyków. Codzienność emigranta i wędrowca (ta rodzinna i starcza) jest bolesna i niełatwa do opowiedzenia, dlatego też szuka się tu alternatywnego (i prawdziwego) świata w dziedzictwie kulturowym Europy, by znajdować wzorce umożliwiające zrelacjonowanie i zachowanie świata oglądanego i podsłuchanego, począwszy od juwenilnych artykułów dziennikarskich, szkiców niedoszłego dziennikarza w Lipsku czy korespondenta Radia Wolna Europa. Wrażliwość Máraiego na słowo jest ogromna, dlatego układa on w albumie wspomnień i albumie swoich powieściowych światów kolekcje europejskich znaków kultury, katalogi aforystycznych myśli zatrzymujących paradoksy niedefiniowalnego świata - relacji, możliwości, zachowań, dopóki bowiem trwa opowieść i możliwe jest pisanie, dopóty trwają życie i sens.

Obok notatek, biograficznych minikompendiów, zapisów o charakterze traktatowym, reportażowych diagnoz kultury i przemian politycznych - rysuje w dzienniku Márai epikryzy chorobowe żony i swoje własne, coraz bardziej powściągliwie notując każdy dzień odchodzenia ukochanej Loli, śmierci, kremacji, pogrzebu. Pisze W 1968 roku o istocie śródziemnomorskiego światła, które ożywia świadomość (1968; D, 376), wskazuje jako emigrant powracający do swojej Europy, jak ważne okazują się wszelkie doświadczenia przełomów i przemian, choć niezwykle przenikliwe wydaje się tu stwierdzenie: „To, co czasami myślałem o Europie, gdy byłem 
po tamtej stronie oceanu, w Ameryce, teraz, będąc znów w Europie, obserwuję bardziej bezpośrednio: otóż to, co nazywa się zwykle «Dziejami», już się w Europie nie «dzieje»" (r968; D, 377).

Podobnie jak wielcy pisarze realiści - Mann, Dostojewski, Prus czy Proust, snuje Márai wariacje na podobne tematy, ciągle zdaje się opowiadać - mimo różnorodnych konstrukcji fabularnych, zmieniając plot swej opowieści - o traumie niemożliwości, nieumiejętności widzenia rzeczywistości, ułomności ludzkiej percepcji, niewiedzy o naszym doświadczeniu, braku pewników, o tym, że paradoksy tworzą nasze doświadczenie bądź przypadkowe relacje. O tym, że warto nieprzepracowane relacje, wspomnienia i doświadczenia, zdobyte w dojrzewaniu do europejskiej przestrzeni identyfikacji (jak w Żarze, Zazdrosnych czy Znieważonych), domykać i do nich wracać.

Márai jest opowiadaczem świata, którego może nigdy nie było. Europy, której nie było mu dane było doświadczyć, więc mógł ją po prostu stworzyć. Doświadczenie (i swoista trauma) emigracji oraz nostalgia wiecznie traconej tożsamości historyczno-politycznej (tylko tej dosłownej) nie spowodowały jednak zapomnienia. Trauma rodzinności w rodzinnym albumie spowodowana jest również nieopisywalnym doświadczeniem prywatnym. W 1939 roku Máraim urodził się syn - Kristóf, który zmarł w miesiąc później - jak dowodzi tego tłumaczka i znawczyni spuścizny Máraiego, Teresa Worowska - na skutek krwotoku wewnętrznego ${ }^{27}$. By ocalić od zapomnienia nieobecne, pisarz decyduje się na wieczną żeglugę ku przestrzeni języka, kultury, rodzinności czy europejskości, która ulega przekształceniom i podlega zmiennym definicjom. W monografii Pośmiertne dzieje Austro-Wegier historyk Adam Kożuchowski redefiniuje więc słusznie konieczność obrazowania specyfiki monarchii austro-węgierskiej, kiedy w kontekście mitów i stereotypów, kiczu (w kontekście rozpoznań i diagnoz Brocha) i nostalgii w różnych typach obrazowania, pisze:

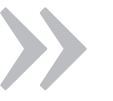

Motywem, a może tylko konwencją stylistyczną, skłaniającym wielu autorów, pozornie dalekim jakiejkolwiek ideologii, do ewokowania obrazów austro-węgierskiej rzeczywistości, wydaje się jakaś forma nostalgii za przeszłością - rzeczywiście obecna w najróżniejszych wizerunkach monarchii, zarówno apologetycznych, jak i przesiąkniętych trzeźwym krytycyzmem. Mogła to być nostalgia samoistna, przechadzająca się bez celu po ogrodzie pamięci, w odróżnieniu od nostalgii słynnego autora słów „dziś piękność twą w całej ozdobie widzę i opisuję, bo tęsknię po tobie", uporczywie wyglądającego przyszłego 
odrodzenia ojczyzny. W przeciwieństwie do Polaków pod zaborami, austriaccy pisarze osieroceni przez upadek monarchii, nawet jeśli nad nim ubolewali, nie snuli wizji jej odrodzenia (w odróżnieniu od publicystów i historyków); najwyraźniej wizja taka nie tylko nie wydawała się wówczas realistyczna, ale nawet pociągająca ${ }^{28}$.

\section{W STRONĘ RODZINNOŚCI}

Bohaterowie powieści Máraiego to ludzie uwikłani w trudne, niewyjaśnione i często zapomniane historie rodzinne, wydziedziczeni z miejsc, których już nie ma, które zmienił bieg historii bądź kazał je wymazać z pamięci. Takie powroty zwłaszcza w cyklach powieściowych - z natury prowokują do myślenia o całości, ciągłości i mają w zamyśle następstwo i próbę „ratunkowego” konstruowania fabuły rodzinnej oraz tła historycznego epoki, która odchodzi bądź odeszła, jak w cyklu Dzieto Garrenów.

Losy mieszczańskiej rodziny z ,jakiegoś” miasta Europy Środkowej zmienia wir II wojny światowej. Losy te ukazują specyficzną „samą prawdę” (chęć jej opisania wyjawia bohater Znieważonych w przedmowie) - przez co można rozumieć prawdę pisarza, doświadczeń, rodzinności i konwencji opowieści. To ciekawy przykład wypróbowywania i przekraczania konwencji realizmu. Od wszechwiedzącego narratora pierwszych trzech części sagi rodzinnej przechodzi się tu do pierwszoosobowej narracji, monologów i wywodów często również w mowie pozornie zależnej jakby od tego typu narracji zależały autentyczność przeżycia i możliwość subiektywnego ujawniania meandrów historii. A ta u Máraiego zawsze jest postrzegana z poziomu „mikro” i stanowi często perspektywiczny obraz zsubiektywizowanej historii, doświadczany jednorazowo i wyjątkowo, burząc tym samym konwencje pewności „makro”, historii wielkiej i fałszywej. Wszechwiedzące (referencjalne) wzorce opowiadalności opisujące (a nie konstruujące) rzeczywistość tekstową i „świat literackości” (termin Kazimierza Bartoszyńskiego ${ }^{29}$ ) zostają tu niejako skompromitowane, okazują się niepewne i cząstkowe. Nie oddają dobrze zarówno przemian, jak i kruchości doświadczeń historycznych z perspektywy jednej rodziny (jak u dwudziestopięcioletniego Tomasza Manna w jego Buddenbrokach).

Rodzinność w cyklu Dzieto Garrenów jest podwójnie trudna i niemożliwa do opisania i opowiedzenia - zarówno ze względu na skomplikowane relacje i rozpad więzi rodzinnych, jak i tożsamość wydziedziczonego, którego decyzją wielkiej historii

29 Termin używany przez Kazimierza Bartoszyńskiego. Zob. m.in. idem, Kryzys czy trwanie powieści. Studia literaturoznawcze, Kraków 2004. 
wyrzuca się poza obręb kraju, skazując na podwójną obcość - narodową i językową. Tajemnice rodzinnej sagi wiodą od węgierskiego miasteczka, które po traktacie w Trianon znalazło się poza granicą Węgier, przez różne koleje trudnych relacji rodzinnych (La, Emmánuela, Edit, Tamása, Edgara) aż do Paryża lat 3o. - w którym główny bohater, Péter - pisarz urodzony w Europie (nazywany przez siebie bohaterem przez sam fakt urodzenia, jak sam wyznaje w przedmowie do Znieważonych) słyszy przemówienie Hitlera i doświadcza berlińskiego szaleństwa wiecu nazistów w Pałacu Sportu czy musi się uporać z legitymizacją władzy nazistowskiej przez Tamása, kiedy ten wierzy w „nihil” kulturowe i przyczepia do klapy marynarki znaczek nazistów . Trudna rodzinność - prywatna i historyczno-polityczna - jest jak wyspa: „Wyspa miała kształt nieregularnej cegły; stając dęba, wyłaniała się z morza jak zabłąkana, niewielka skała, która pozostawiona samej sobie, niespokojnie przypatruje się światu i już nie potrafi powrócić do licznej rodziny"30.

Żar jest z kolei swoistą suitą muzyczną na temat przyjaźni i dojrzewania dwóch chłopców w wiedeńskiej atmosferze moderny - Konrada i Henryka, których los po latach ponownie zetknął ze sobą jako kompozytora i generała. Wiedeńska atmosfera dojrzewania bohaterów, $\mathrm{z}$ walcami młodego Straussa gwizdanymi na ulicach, atmosfera oniryczna, senna, przymglona, zostaje melancholijnie zatrzymana w kadrze:

Wiedeń już spał. Spał głęboko, i padał śnieg. Cesarz także już spał w Burgu, spało pięćdziesiąt milionów ludzi w krajach cesarza. Syn oficera gwardii [Henryk - dop. D.M.O.] czuł, że on też ma coś wspólnego $\mathrm{z}$ tą ciszą, on także czuwa nad snem cesarza i pięćdziesięciu milionów ludzi, i nad ich bezpieczeństwem, czuwa nawet wtedy, gdy nic nie robi innego, jak tylko nosi ze czcią mundur, wieczorami bywa w towarzystwie, słucha walców, pije czerwone francuskie wino, a damom i dostojnym panom mówi dokładnie to, czego od niego oczekują ${ }^{31}$.

Muzyka dla Konrada okazywała się tajemniczą przestrzenią wyzwolenia i wolności twórczej. Konstrukcja fabuły odtwarza spotkanie po latach dwóch przyjaciół, których losy rozeszły się z racji historyczno-politycznych konieczności i różnic statusu materialnego. To spotkanie po latach - ze wspomnieniami - wygląda podobnie jak w miniaturze Orzeszkowej Ogniwa z tomu Melancholicy, gdzie widzimy spotkanie arystokraty - hrabiego Strumienieckiego i biednego Żyda - Berka, którzy 
w obliczu upływającego czasu i nadchodzącego kresu stają się sobie na powrót bliscy i przeżywają podobne doświadczenia odchodzenia.

Márai - jako uczestnik przewrotów w kraju i jako emigrant - im bardziej traci doświadczenie rodzinności, więc i środkowoeuropejskości (skoro ono niejako odgórnie okazuje się synekdochą mapy relacji rodzinnych), tym bardziej je odzyskuje. Jako pisarz odzyskuje je nie tyle w geście hermeneutycznej anamnezy diagnozującej mapę Europy Środkowej i rodzinnych Węgier czy Koszyc, ile w samej chęci powrotu - melancholijnego zatrzymania nad przemijaniem czegoś, czego już nie ma. Dokonuje tu, żeby posłużyć się pojemną formułą Feliksa Netza, „czarowania ludzi”32, ale i czarowania ludźmi - bohaterami i czytelnikami, konstruując językowy obraz świata, który mija albo bezpowrotnie zatarł swe wyraziste i barwne kontury i może być oglądany tylko w sepii albumowej pocztówki rodem z XIX wieku. Tu różnicujące doświadczenie stabilizuje, a poczucie dystansu wyostrza tylko rysy. Odseparowanie, każdy wyjazd czy ucieczka pisarza (a także ucieczki jego bohaterów), jest zarazem powrotem.

\section{W STRONĘ SIEBIE}

Autor powieści Sindbad wraca do domu jest pisarzem zbierającym doświadczenia dwudziestowiecznego chaosu rzeczywistości, zmieniających się politycznych oraz kulturowych wzorców, także wzorców pisarskich, w epoce ciągle niemożliwej do zdefiniowania dwudziestowieczności (w której uczestniczy, choć przecież nie wie, zapisując siebie i świat w dzienniku i powieściach, jak długo jeszcze będzie w niej uczestniczył). Jest uczestnikiem i świadkiem zmian warty. I jako ten, który rejestruje „przełomowość”, pozostaje wielkim realistą, dla którego reprezentacja świata tekstowego jest jedynym albumem traconej, ale odzyskiwanej w strukturze frazy i fabuły, rodzinności. Model tej rodzinności ulega przekształceniom, zależy od perspektywy widzenia, przemiany, odchodzenia, powrotu (wiecznego powrotu do źródeł Europy i własnego siebie), które kataloguje, konstruujących z kolei świat pojedynczych sekwencji zdarzeń, a przez to znaczeń. Okazuje się on galerią przedziwności, możliwych do spotkania tylko tu - jak w albumie - przełomów, epok, ludzi, których los, czas i doświadczenie pozwala się spotkać. To spotkanie rzeczywistości „tu i teraz” nie byłoby możliwe, ale utrwalone właśnie jako „tu i teraz”, w wiecznej teraźniejszości melancholijnego ciągu sensów i chęci utrwalenia doświadczenia jest realne (jako potencjalny i faktyczny stan rzeczy). W doświadczeniu utrwalania pamięci - jak w potoku życia składającego się z samych epifanii codziennych momentów - chce się zatrzymać wszystko, co zmienne, więc 
nietrwałe. Márai próbuje uchwycić horyzont tekstowego ogrodu przedziwności, które zebrał z ginącego środkowoeuropejskiego świata wartości. Próbuje również stworzyć tekstowe panoptikum niehomogenicznych obrazów, które dzięki palimpsestowej i anamnetycznej strukturze i lekturze pozwalają w ruchu zmieniających się elementów ułożyć trwały album reguł świata dotykalnych jedynie w płynności jego doświadczeń, album paradygmatu środkowoeuropejskiej kultury, myślenia, typu emocjonalnego, specyficznego przeżywania szczegółów rzeczywistości, której istota - jak pisze o tym Márai - zanika.

Autotematyzm i autobiograficzne wzorce zapisywane w albumie powieściowej fabuły życia pomagają Máraiemu uporać się z procesem świadomego odchodzenia kultury, skoro - jak napisał w Magii - miniaturze o strukturze szkatułkowej, dotyczącej niemożliwości opowiedzenia życio-pisania oraz ujęcia paradoksów realnego i fikcyjnego świata, w którym pisarz i każdy człowiek uczestniczy:

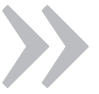

Poczekaj, proszę - powiedział pisarz - opowiem ci coś, o czym nigdy jeszcze nie mówiłem. Swego czasu wierzyłem, że potrafię o tym napisać ${ }^{33}$.

- Chodzi o to [...], że pisanie ożywia postaci, które przynależą do powieści, mobilizuje osoby, które dotychczas gdzieś tylko żyły i były odlewaczami miedzi albo ciotkami, albo pięknymi kobietami, albo generałami, i nic nie wiedziały o swoim losie ${ }^{34}$.

Wiele jest luster za nami, a z każdego macha w naszą stronę jednakowo wypaczone i znajome przeznaczenie... Czym jest pisanie? Czym jest życie? Co jest życiem na jawie, a co snem? Co jest światem, a co jest imaginacją? Jesteśmy pisarzami, naszym zadaniem jest odpowiedzieć na te pytania. Czy wierzysz, że nie tylko pisarz kształtuje życie powieści, ale też powieść kształtuje życie pisarza? Według Nietzschego,

33 S. Márai, Magia, tłum. I. Makarewicz, Warszawa 2008, s. 293. Warto tylko dodać, że opowieść o samobójstwie pisarza Walerego i istocie rozumienia przez niego prawideł „czytania” znaków rzeczywistości, jest możliwa do opowiedzenia jedynie poprzez kolejne piętra narracji i kompozycji zapośredniczającej. To częsty „chwyt” fabularny, który stosuje Márai w jego kolekcji światów, którym grozi unicestwienie, jeśli nie zostaną opowiedziane. Historia Walerego z Magii jest opowieścią w opowieści o losie „śnienia” rzeczywistości i niemożliwości nazwania jej prawideł, mechanizmów, wreszcie - jej wyobrażenia, które jak sen śniony we śnie (parafrazując słowa bohatera, który opowiada historię Walerego) odbija jedynie lustrzaną istotowość bytu, jedyną fikcjonalną realność, która przecież przynależy tylko do śniącego - świadomego, że śni.

Osobnym elementem jest sam fakt samobójczej śmierci pisarza strzałem z broni. Kilkadziesiąt lat później taki los wybierze dla siebie autor Magii, a może raczej podzieli los żywych figur jego pisarskiej wyobraźni. 
otchłań odwzajemnia spojrzenie temu, kto długo w nią spogląda... ale to jest już truizm. Możliwe, że bohater powieści przygląda się czasem pisarzowi, który obudził wokół niego odcienie magicznego istnienia, i swoim podobnym do snu losem oddziałuje na los twórczy? Wciska broń w rękę tego, który jemu wepchnął broń? Mści się na tym, który go wyczarował z podziemnego świata nicości i dał mu jakieś życie i los? Czy to wszystko jest możliwe...? Za dnia, w kawiarni, nie jest możliwe. Ale pomiędzy dniem a nocą też jest swego rodzaju przestrzeń... rozumiesz już? Ta przestrzeń to magia ${ }^{35}$.

Autotematyzm prozy Máraiego - dwudziestowiecznego flâneura, ironisty, mędrca - uobecnia się w figurze świadka zdarzeń. Pomaga uczestniczyć w rodzącej się na gruzach monarchii austro-węgierskiej rzeczywistości, oglądanej i podglądanej z dystansem i nieskrywaną ironią dawności świata Franciszka Józefa panującego nieprzerwanie przez 68 lat, a także późniejszego świata przewrotów politycznych, traumy wydarzeń roku I968 i opresyjnych działań reżimu komunistycznego.

Świadomie, w akcie najwyższej pewności, pisarz odbiera sobie życie w 1989 roku, kiedy zabrakło mu rodziny, a więc i podstawowego języka oraz świata, który stabilizował wszystko to, co określało w jego biografii „stare” Węgry; kraj, którego - parafrazując formułę Charlesa Baudelaire'a - „nie ma już”. 


\section{Dawid Maria Osiński}

\section{The ALbuMs OF LOST FAMILIARITY: THE EXPERIENCE OF THE CENTRAL- -Eastern Europe in Sándor Márai's prose - a FeW approximations}

The article focuses on the reflection of the Hungarian writer, Sándor Márai (1900-1989), about the family and Europeanism as identity traits. His novels, prose miniatures, essays, travel reports, and a diary, are analysed. The aim is an attempt to describe the experience of the Central-Eastern Europe in prose and intimate writing of the author of Embers, as well as to diagnose the specific nature of private (family) and European identity of the character in such geopolitical map.

For Márai Central Europe is a multicultural project of shattered identity, written project of space, far from the status of a federation of states. In his fictional worlds the writer - as if in the layer of language and plot - constructs Hungary, the former glory of the monarchy and the identity of Central Europe.

The categories differentiating return to the sources, the collection of "lastness" (i.e. past experiences, meetings, reports, events) and melancholy as textual presence of a "lack" of language and search for space, which can be invoked as its own (a kind of "uterine myth"), form the writer's reflection on the trauma: "nothing that hurts". Márai's melancholia is both an existential experience, as well as the writing process - narrative and linguistic. These experiences contribute, through the prose and intimate works of Márai, as an album of "impossibility", showing a record of trauma of the Central-Eastern European experience, and displaying the impossibility of participation in family and culture. 